\title{
Growth Strategies of Three Laminaria Species (Phaeophyceae) Inhabiting Different Depth Zones in the Sublittoral Region of Helgoland (North Sea)
}

\author{
K. Lüning \\ Biologische Anstalt Helgoland, D-2192 Helgoland, Federal Republic of Germany
}

\begin{abstract}
On European coasts, Laminaria digitata does not inhabit the deeper kelp zone; this is dominated by L. hyperborea and (locally) L. saccharina. Sporophytes of three Laminaria spp. were cultivated from unialgal gametophyte cultures in the laboratory and transplanted into the field in February, at depths of 2, 4.5 or $7 \mathrm{~m}$ below M.L.W.S. Near Helgoland, the deepest kelp (L. hyperborea) occurs at $8 \mathrm{~m}$, and older plants of L. digitata are not found below $2 \mathrm{~m}$ depth. Photosynthesis was light-saturated in all three species, irrespective of cultivation depth, at photon flux densities above about $150 \mu \mathrm{E} \mathrm{m}^{-2} \mathrm{~s}^{-1}$ (corresponding to an irradiance of $30 \mathrm{~W} \mathrm{~m}^{-2}$ ). The experimental plants of L. digitata and $L$. saccharina produced much bigger blade areas in spring and summer at all depths than $L$. hyperborea. In July, the latter species completely ceased blade growth and $L$. saccharina reduced its growth rate very much. L. digitata, however, first reduced its growth rate in September (by about $50 \%$ ), so that at the beginning of the dark season, from October onwards, its blades consisted of much younger tissue, resulting in a lower content of reserve materials per plant than in the case of the other two species. The long-persisting, high growth rate in $L$. digitata may be interpreted as adaptation to life in the sublittoral fringe; however, it obviously prevents the species from perennial colonization of the deepest parts of the kelp zone. The finding that the three Laminaria spp. reduced or ceased growth at different times during the year, under otherwise identical conditions of temperature, nutrients, light intensity or light quality, suggests the possibility that none of these factors actually trigger the seasonal growth behaviour of these species.
\end{abstract}

\section{INTRODUCTION}

On most European coasts Laminaria digitata inhabits the uppermost part of the sublittoral region, whereas L. hyperborea and (locally) L. saccharina dominate the middle and deeper parts of the kelp zone (Kain, 1962; Castric-Fey et al., 1973; Gayral \& Cosson, 1973). L. digitata is well adapted for colonizing the upper sublittoral region, e.g. by possession of a flexible stipe due to which the thalli form a flat-lying mass when the population is exposed to drought or cold at extreme low water. The question is still open why adult sporophytes of $L$. digitata are excluded from the deeper kelp zone. It may be possible that this species is photosynthetically a 'sun plant', which is not able to produce sufficient photosynthate for growth in the 'shadow' regions of the deeper kelp zone. An alternative explanation might be sought in a genetically fixed allocation pattern of carbon into either growth, or formation of reserve materials. This pattern may be adequate for the upper, but not for the deeper parts of the kelp zone. In the present work the question was approached experimentally by transplanting laboratory- raised sporophytes to different water depths in the field, and investigating the photosynthetic and growth performance of the experimental plants.

\section{MATERIALS AND METHODS}

\section{Cultivation in the Laboratory}

Enriched seawater (PES; Provasoli, 1968) was used throughout for cultivation in the laboratory. Unialgal gametophyte cultures derived from wild Helgoland sporophytes were set up in red fluorescent light, as described in detail by Lüning et al. (1978). For obtaining sporophytes the filamentous gametophytes were gently ground with mortar and pestle. The few-celled gametophyte fragments were inoculated on white, roughened PVC plates $(5 \times 3 \mathrm{~cm}, 6 \mathrm{~mm}$ thick) which were situated in stagnant PES on the bottom of a plastic tank $(50 \times 50 \mathrm{~cm}, 20 \mathrm{~cm}$ high). The sticky gametophyte fragments settled on the PVC plates within a short time. In white fluorescent light (Osram $40 \mathrm{~W} / 19$; illuminance $2000-2500 \mathrm{~lx}$ ) and at a tempera- 
ture of $10^{\circ} \mathrm{C}$ the gametophytes matured within $8-12 \mathrm{~d}$ (Lüning and Dring, 1975). Sporophytes, $1 \mathrm{~mm}$ long, were obtained 3 weeks after inoculation. At this stage most of the sporophytes were mechanically removed from their substrate, leaving 10-20 sporophytes per PVC plate. Subsequently, cultures were aerated and PES was changed every $4 \mathrm{~d}$.

Six weeks after inoculation the sporophytes had reached lengths of $2-3 \mathrm{~cm}$ and were transferred into a seawater shower (Chapman, 1973a). Basically, this consisted of an Eternit tank $(150 \times 100 \mathrm{~cm}, 70 \mathrm{~cm}$ high; seawater volume, $185 \mathrm{l}$; seawater filtered through Seitz asbestos filter K 5, and renewed every 2 d) in which the

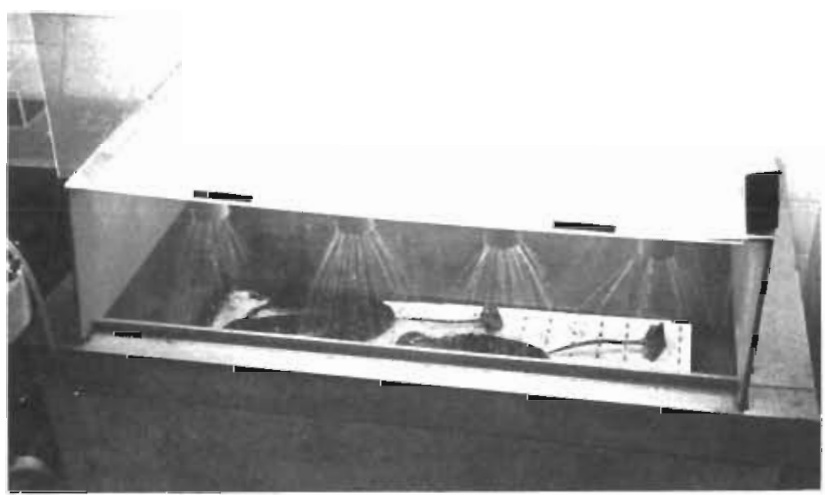

Fig. 1. Seawater shower used for cultivation of laminarian sporophytes

algae were sprayed by recirculated water from above (Fig. 1). For the first two weeks the algae were situated $2 \mathrm{~cm}$ below water level, but afterwards $5 \mathrm{~cm}$ above. After two months in the shower culture, the sporophytes had reached blade lengths of $5-25 \mathrm{~cm}$ and had formed rigid stipes and haptera. The plants on each PVC plate were thinned out again, leaving $3-5$ plants per plate.

\section{Cultivation in the Sea}

By mid-February the experimental plants were transferred to an underwater station (iron grid, $2 \times 1$ m) situated in the sea near Helgoland at $2 \mathrm{~m}$ depth (all depths expressed as meter below Mean Low Water Spring Tide'). By the end of April the experimental plants were transferred to their final positions, i.e. to underwater stations at $7,4.5$ or $2 \mathrm{~m}$ water depth $(45$ PVC plates for each species and at each experimental depth). Growth measurements (see below) were performed from May until November, at seven dates. For this purpose the plants were surfaced by divers and 10 plants of each of the 9 experimental groups ( 3 species at 3 depths) photographed on board a ship. Measurements were taken from the photographs.

At $7 \mathrm{~m}$ depth the plants were lost by the end of July due to heavy infestation by the bryozoan Membranipora membranacea. At the lower depths only small portions of the blades had been infested and were mechanically cleaned. A further loss of experimental plants was encountered by the beginning of October, when all individuals of Laminaria digitata disappeared from the underwater station at $2 \mathrm{~m}$ depth due to a storm.

\section{Growth Measurements}

The method of determining growth in blades of Laminaria spp. is based on the fact that elongation occurs within the lowermost $10 \mathrm{~cm}$ of the blade (Sundene, 1964). At each inspection date, a hole $6 \mathrm{~mm}$ diameter) was punched at $10 \mathrm{~cm}$ distance from the junction between stipe and blade in one experimental plant on each PVC plate. The hole marked the upper edge of the area $L 1_{t-1}$ (Fig. 2). At the next inspection

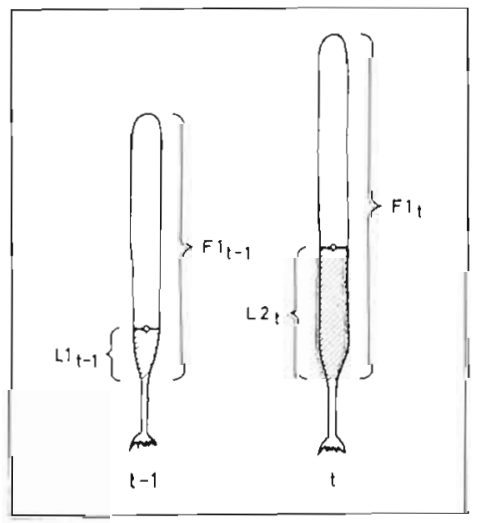

Fig. 2. Area parameters of Laminaria spp. used for calculation of growth rates (see text for further explanation)

date it marked the upper edge of the area $L 2$. The increase in blade area $(Z)$ which occurred in the interval from date $t-1$ to date $t$ results from

$$
Z=L 2_{t}-L 1_{t-1}
$$

The total blade area $F 1_{t-1}$ of a plant at date $t-1$ increases until date $t$ according to

$$
F 2_{i}=F 1_{t-1}+Z
$$

where $F 2$, denotes a fictive total area which is smaller than the actual total area $F 1_{\text {t }}$ at date $t$, since not only growth has occurred, but also loss of tissue at the distal end of the blade due to erosion. The tissue lost (E) can be determined from

$$
E=F 2_{\imath}-F 1_{\imath-\uparrow}
$$

The relative growth rate $R$ (Evans, 1972) was calculated on a monthly base ( $C=$ number of days between inspection dates) and refers to total blade area:

$$
R=\left(\log _{e} F 2_{t}-\log _{e} F 1_{t-1}\right) \quad 30 \cdot C^{-1}
$$

Finally, an enlargement factor $P$ was calculated from

$$
P=\operatorname{antilog} R
$$




\section{Gas Exchange Measurements}

For determination of photosynthetic and dark respiration rates representative plants of the experimental groups were collected by divers one day prior to the measurements. Discs of $21 \mathrm{~mm}$ diameter were cut from the middle of the blades and kept dark overnight in flowing seawater $\left(12^{\circ} \mathrm{C}\right.$ for measurements performed in May and June, $17{ }^{\circ} \mathrm{C}$ in August). Oxygen exchange of the disc was measured in a circular Plexiglas chamber $(20 \mathrm{ml}$ volume) supplied with an oxygen electrode (Hydrobios, Kiel). The seawater in the chamber was stirred by a magnetic bar. The oxygen electrode was calibrated both in airsaturated water and in a $1 \% \mathrm{Na}_{2} \mathrm{SO}_{3}$ solution, at constant temperature. Values for oxygen content in air-saturated seawater were taken from the tables presented by Green and Carritt (1967).

The oxygen measuring chamber was illuminated from above by a Leitz Prado Universal projector (quartz iodide lamp, $24 \mathrm{~V}, 250 \mathrm{~W}$ ). The projector was combined with Schott colour glass filters BG 38 (2 mm thick) and GG 4 (1 $\mathrm{mm}$ thick) in order to imitate underwater spectral distribution at moderate water depths when Jerlov water Type 5 prevailed (see Lüning, 1980a). Ten different light intensities were achieved by Schott neutral glass filters. The latter were mounted in a filter wheel and changed automatically every $4 \mathrm{~min}$. At the same time the measuring chamber was flushed with membrane-filtered seawater (Millipore, $0.45 \mu \mathrm{m}$ ). This procedure ensured that all measurements took place at $80-90 \%$ of the oxygen content of airsaturated seawater. The signals from the oxygen electrode were monitored by a compensation recorder (Micrograpgh BD5, Kipp \& Zonen, Delft, Holland). Photon flux density was measured by means of a Lambda quanta meter (Lambda Instruments Corp., Lincoln, Nebraska, USA). The conversion factors for the projector light field, as well as for the white fluorescent lamps used, were

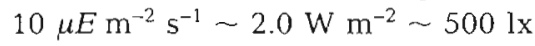

\section{Determination of Ash and Reserve Materials}

By mid September up to 20 individuals from each experimental group (except the 7 -m plants) were harvested for determination of area / dry weight $\left(103{ }^{\circ} \mathrm{C}\right)$ relationships and of reserve materials. Parallel to this, plants (of unknown age) from the wild populations were harvested. The cultivated plants had an age of 1 year ( 7 months in the sea), when harvested. Dry blades were pulverized (Bühler homogenisator) and sieved (mesh width $80 \times 80 \mu \mathrm{m}$ ), and the resulting algal powder was used for further analysis. The ash content was determined after combustion at $400{ }^{\circ} \mathrm{C}$ for $20 \mathrm{~h}$
(Heraeus combustion furnace MR 170). The mannitol content was determined by oxidation for 1 min with periodate according to the method outlined by Cameron et al. (1948). Laminarin was assessed after neutralizing the hydrolyzate of $200 \mathrm{mg}$ algal powder in 40 $\mathrm{ml} 1 \mathrm{~N} \mathrm{H}_{2} \mathrm{SO}_{4}\left(4 \mathrm{~h}\right.$ at $100^{\circ} \mathrm{C}$ ) using the glucose-oxidase test (Merck, GOD test).

\section{RESULTS}

From the beginning, the sporophytes of Laminaria saccharina exhibited the highest growth rate. At an age of 3 months (mid-February), when the experimental plants were transferred from the seawater shower into the field, maximum blade length was $25 \mathrm{~cm}$ in this species, but only $8-10 \mathrm{~cm}$ in the other two species. By mid-May, when growth measurements were started, mean values of blade area (at $2 \mathrm{~m}$ water depth) were $4.6 \mathrm{dm}^{2}$ in $L$. saccharina, and 2.9 or $1.5 \mathrm{dm}^{2}$ in $L$. digitata or L. hyperborea.

From the growth records illustrated in Figures 3 and

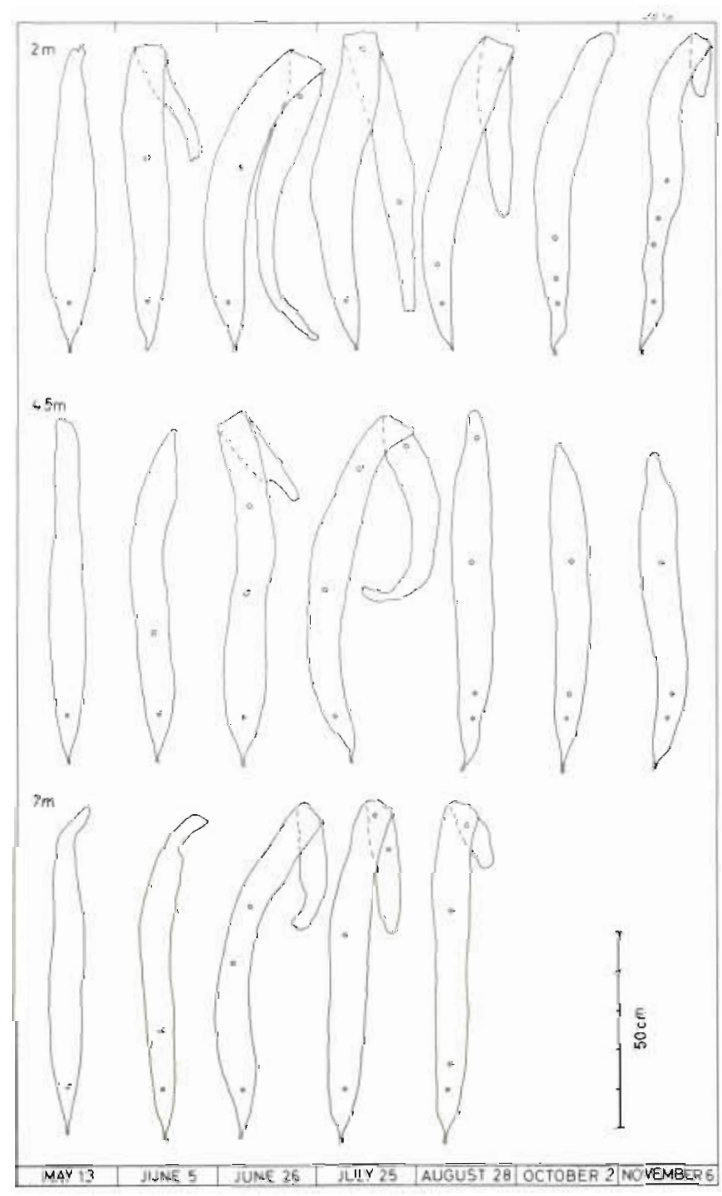

Fig. 3. Laminaria saccharina. Records of the growth of experimental plants cultivated at $2 \mathrm{~m}, 4.5 \mathrm{~m}$ or $7 \mathrm{~m}$ water depth near Helgoland 


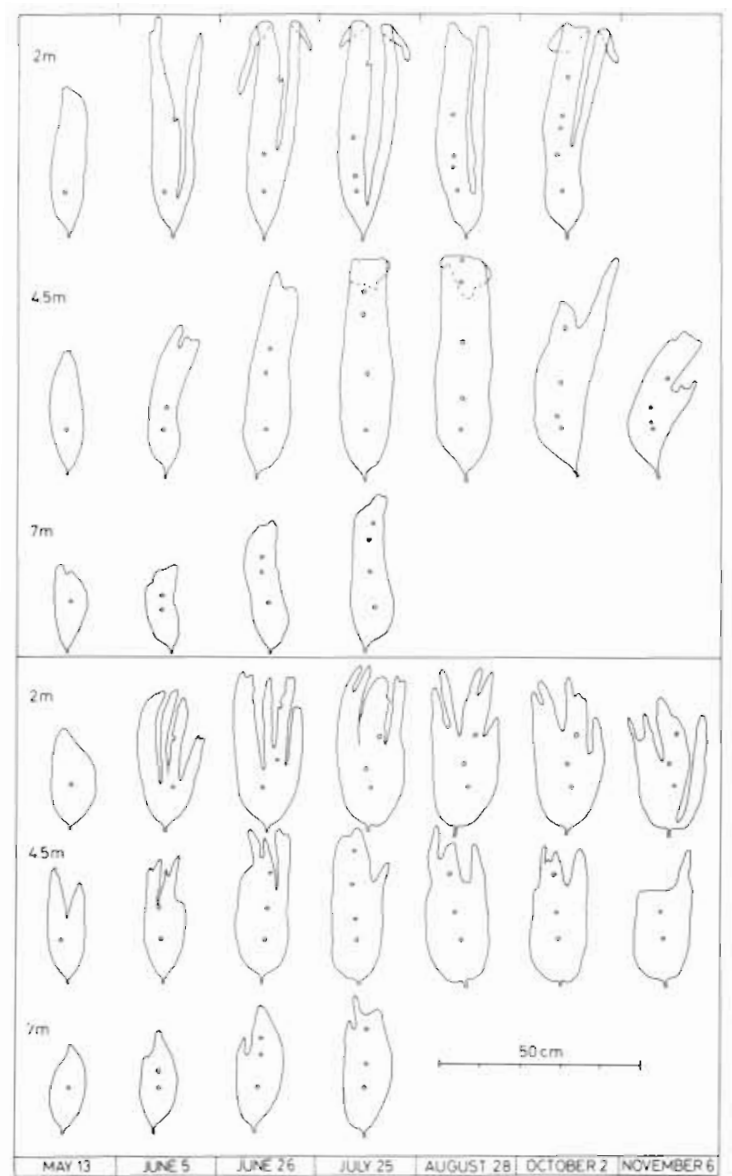

Fig. 4. Laminaria digitata (upper) and L. hyperborea (lower). Records of the growth of experimental plants cultivated at $2 \mathrm{~m}, 4.5 \mathrm{~m}$ or $7 \mathrm{~m}$ water depth near Helgoland

4 , as well as from the seasonal changes of frond area (Fig. 5) the following features are obvious: (1) The maximum frond area occurred in July/August; it amounted to $9-11 \mathrm{dm}^{2}$ in Laminaria saccharina, but to only 5 and $3 \mathrm{dm}^{2}$ in L. digitata and L. hyperborea, respectively (all values at $2-4.5 \mathrm{~m}$ water depth). From September onwards the blade area decreased in all experimental plants, since loss at the distal end surmounted production of new tissue at the base. (2) Blade area at 2 and $4.5 \mathrm{~m}$ water depth was very similar, and only at $7 \mathrm{~m}$ significantly lower than at $2 \mathrm{~m}$. (3) Splitting of the blade in the digitate species depended on cultivation depth. At $2 \mathrm{~m}$, the blades exhibited deep splits by the beginning of June. At $4.5 \mathrm{~m}, 70 \%$ of L. digitata and $L$. hyperborea were deeply split by the end of July. At $7 \mathrm{~m}$ only short splits were observed in $L$. hyperbored and no splits at all in L. digitata.

On October 2 about half the experimental plants of Laminaria saccharina had become sporogenous (irrespective of water depth); on November 6, all of them. The other two species had remained sterile until this date.

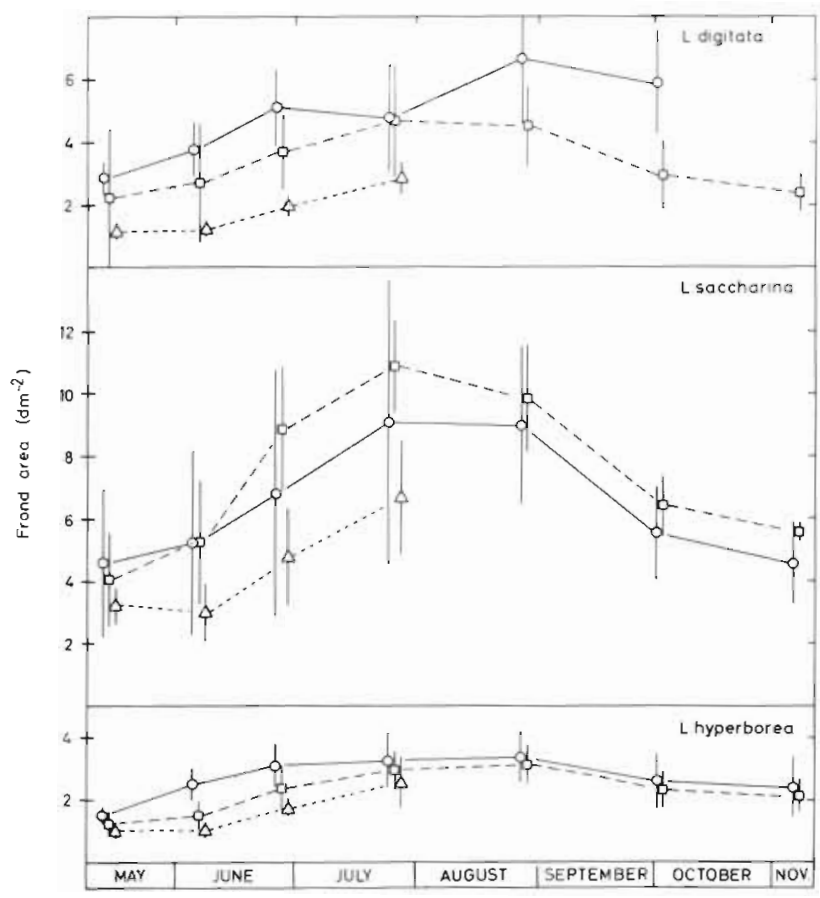

Fig. 5. Laminaria spp. Frond area at $2 \mathrm{~m}(0), 4.5 \mathrm{~m}(\square)$ and $7 \mathrm{~m}(\Delta)$ water depth. Vertical bars: confidence limits $(p=$ $0.05, n=10$ )

Significant differences in growth rate due to water depth could be most clearly detected in May (measuring date : June 5), and also during the summer in Laminaria digitata and L. saccharina (Figs 6 and 7). However the statistic resolution in the growth experiment was not sensitive enough to detect all depth effects on growth, and even some inconsistencies occurred. The relative growth rate (Fig. 7) reached its peak in May in L. digitata and L. saccharina at $2 \mathrm{~m}$ depth, or in June (measuring date: June 26) in all other experimental groups. The peak values of relative growth rate per month were in the range $0.5-0.8$, corresponding to an enlargement of frond area by a factor of 1.7-2.2 within $30 \mathrm{~d}$. Considerable increase in blade area occurred in July (measuring date: July 25) in all three species. By August, however, characteristic species-specific differences became obvious. In this month L. hyperborea ceased its increase in blade area completely, $L$. saccharina reduced its absolute growth rate by ca. $80 \%$, but $L$. digitata produced as much blade area as in the months before (Fig. 6). A decrease in growth rate (by $50 \%$, if compared with August) occurred in the latter species only in September (Figs 6 and 7 ).

During the period from mid-May until the beginning of October Laminaria digitata ( 2 and $4.5 \mathrm{~m}$ ) and $L$. saccharina $(2 \mathrm{~m}$ ) enlarged their initial area (as present at May 13) by a factor $P=4$. The corresponding value for L. hyperborea $(2$ and $4.5 \mathrm{~m}$; also L. saccharina at 4 
m) was $P=3$ (Fig. 8). As stated above, $P$ indicates the factor by which the initial area would have been enlarged if no losses of tissue at the distal end of the blade had occurred. The losses from May until October were in the range $42-70 \%$, with $L$. hyperborea exhibiting the lowest loss rate (Table 1 ). The loss rate was very variable from month to month and amounted to $10-40 \%$ per month in L. digitata and L. saccharina and

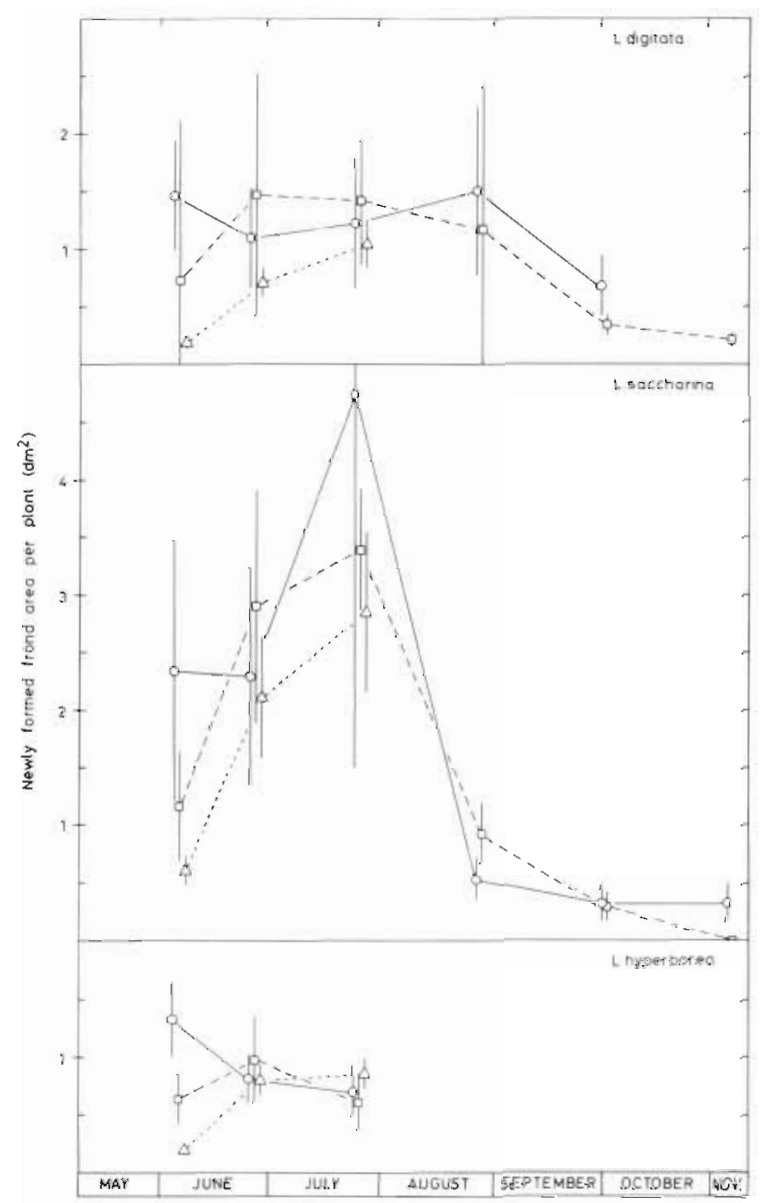

Fig. 6. Laminaria spp. Newly formed frond area at $2 \mathrm{~m}(0)$, $4.5 \mathrm{~m} \mathrm{( \square )} \mathrm{or} 7 \mathrm{~m}(\Delta)$ water depth. Vertical bars: confidence limits $(p=0.05, n=10)$ to $10-30 \%$ in L. hyperborea. No clear relation of loss rate with depth was discerned.

Since the increase of blade area ceased compara-

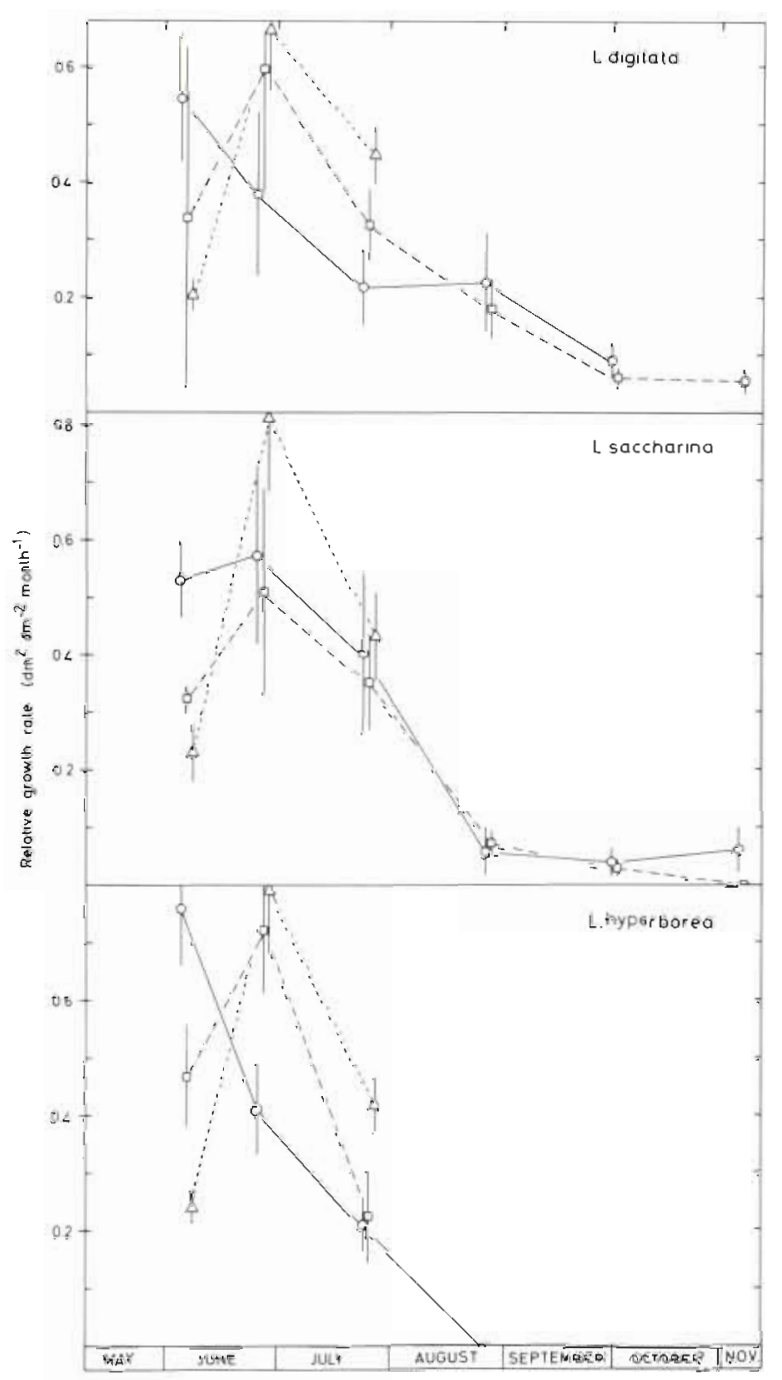

Fig. 7 Laminaria spp. Relative growth rate (per month) at $2 \mathrm{~m}$ $(0), 4.5 \mathrm{~m}(\square)$ or $7 \mathrm{~m}(\Delta)$ water depth. Vertical bars: confidence limits $(p=0.05, n=10)$

Table 1. Total frond area per plant, produced from May 13 until October 2, and frond area lost during the same interval at two water depths (below M.L.W.S.). D: Laminaria digitata, S: L. saccharina, H: L. hyperborea

\begin{tabular}{|c|c|c|c|c|c|c|c|}
\hline \multirow[t]{2}{*}{ Species } & \multirow{2}{*}{$\begin{array}{l}\text { Depth } \\
\text { (m) }\end{array}$} & \multirow{2}{*}{$\begin{array}{l}\text { Frond area } \\
\text { on May } 13 \\
\qquad\left(\mathrm{dm}^{2}\right)\end{array}$} & \multirow{2}{*}{$\begin{array}{l}\text { Enlargement } \\
\text { factor } \\
\text { May } 13-\text { Oct. } 2\end{array}$} & \multirow{2}{*}{$\begin{array}{c}\text { Total frond } \\
\text { area } \\
\text { May } 13-\text { Oct. } 2 \\
\left(\mathrm{dm}^{2}\right)\end{array}$} & \multirow{2}{*}{$\begin{array}{l}\text { Frond area } \\
\text { Oct. } 2 \\
\left(\mathrm{dm}^{2}\right)\end{array}$} & \multicolumn{2}{|c|}{$\begin{array}{l}\text { Frond area lost } \\
\text { May } 13 \text {-Oct. } 2\end{array}$} \\
\hline & & & & & & $\left(d m^{2}\right)$ & $(\%)$ \\
\hline \multirow[t]{2}{*}{$\mathrm{D}$} & 2 & 2.9 & 3.8 & 11.0 & 5.9 & 5.1 & 46 \\
\hline & 4.5 & 2.3 & 3.7 & 8.5 & 3.0 & 5.5 & 65 \\
\hline \multirow[t]{2}{*}{$S$} & 2 & 4.6 & 4.0 & 18.4 & 5.6 & 12.8 & 70 \\
\hline & 4.5 & 4.1 & 2.9 & 11.9 & 6.4 & 5.5 & 46 \\
\hline \multirow[t]{2}{*}{$\mathrm{H}$} & 2 & 1.5 & 3.0 & 4.5 & 2.6 & 1.9 & 42 \\
\hline & 4.5 & 1.3 & 3.2 & 4.2 & 2.4 & 1.8 & 43 \\
\hline
\end{tabular}


tively early and tissue losses were smallest in Laminaria hyperborea, the life span of the monthly formed blade portions was highest in this species Figures 9 to 11 show the age of different portions of a blade in different experimental groups and the percentage of total blade area they made up at a given time. For example, the tissue formed until June 5 had completely disappeared by the beginning of October in $L$. digitata and $L$. saccharina, whereas it still made up $45 \%$ of the blade area present in L. hyperborea at the beginning of November. About half of the blade area of the latter species consisted at this time of blade portions which were at least 5 months old. The age of $70-80 \%$ of the blade area in early November was $2-3$ months in L. digitata, 3-4 months in L. saccharina and 4-6 months in L. hyperborea (Figs 9 to 11 ).

By September the laminaran content in the blades of Laminaria digitata, cultivated at $2 \mathrm{~m}$ water depth, was

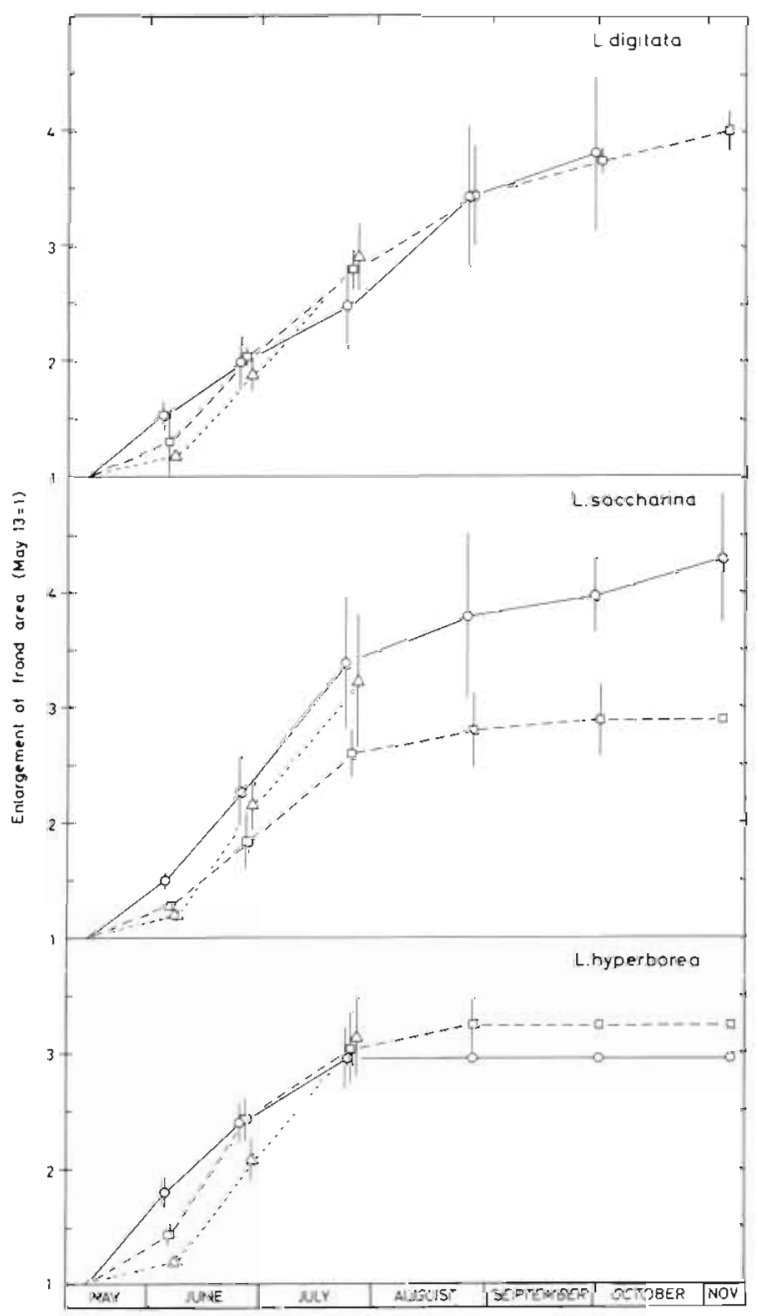

Fig. 8. Laminaria spp. Enlargement of frond area at $2 \mathrm{~m}(0), 4.5$ $(=)$ or $7 \mathrm{~m} \mathrm{(L)}$ water depth. The average area of the fronds attained on May 13th has been set as 1. Vertical bars: confidence limits $(p=0.05, n=10)$ only $2 \%$ of dry weight. The other two species, cultivated at the same depth, contained 5-9 times more laminaran (Table 2). Individuals of the wild population (more than one year old) which were investigated for comparison also exhibited a considerably lower laminaran content in $L$. digitata than in the other two species. The mannitol content was in the range $16-23 \%$ (of dry weight) in all investigated groups, except a low value $(8 \%)$ in $L$. digitata cultivated at 4.5 $m$ water depth. The highest ash and hence the lowest content in organic matter was found in L. digitata. Furthermore, there was a tendency for the ash content of the blades to decrease with increasing water depth (Table 2). The combined dry weight of stipe plus haptera amounted to $6 \%$ (L. saccharina), $11 \%$ (L. digitata) or $23 \%$ (L. hyperborea). By September the stipes were 9-12 cm long (only $4 \mathrm{~cm}$ in L. digitata cultivated at 4.5 $m$ water depth) in the experimental algae. Stipe diameter was $3-5 \mathrm{~mm}$.

The relationship between net photosynthesis and

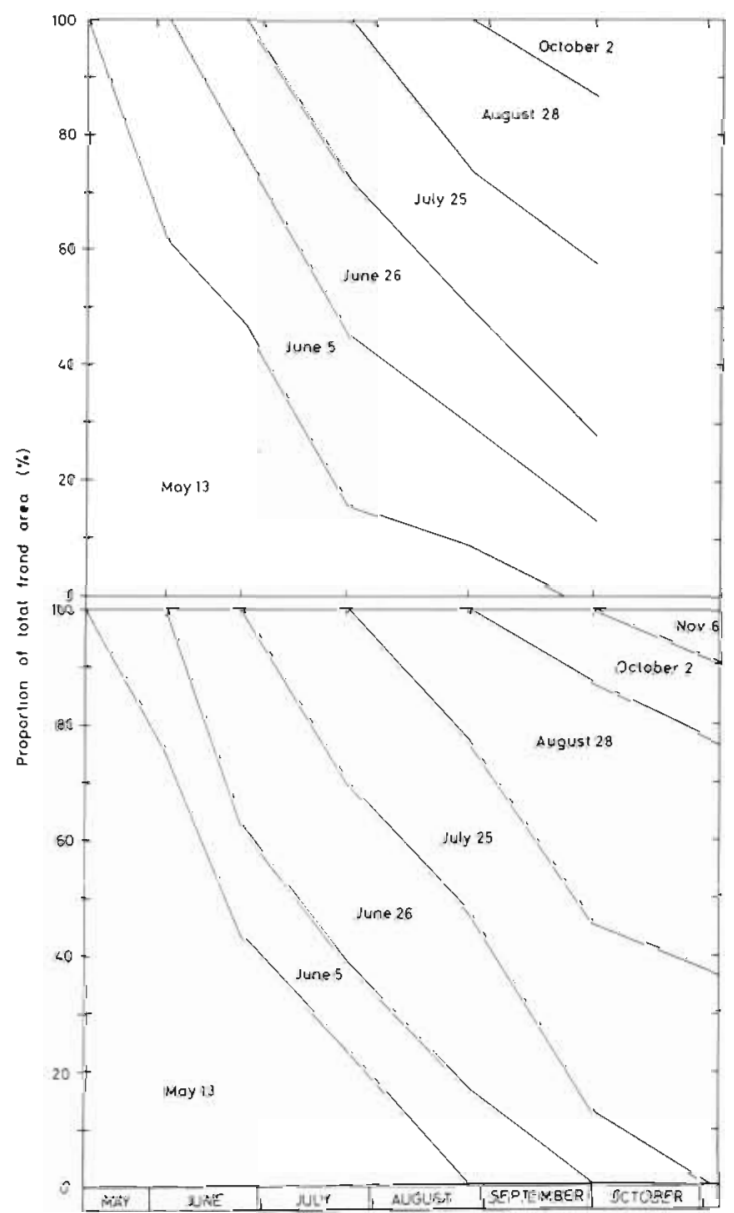

Fig. 9. Laminaria digitata at $2 \mathrm{~m}$ (upper) and $4.5 \mathrm{~m}$ water depth (lower). Proportion of frond area, newly formed between successive investigation dates, of actual frond area at dates given 
light intensity ( $P$ vs $I$ curve) was remarkably similar in all three Laminaria spp., and with respect to the water depth at which the algae had been cultivated. This was found in the experiments conducted in May/June at $12^{\circ} \mathrm{C}$ (Fig. 12), as well as in August at $17^{\circ} \mathrm{C}$ (Fig. 13). Net photosynthesis increased linearly with photon flux density up to $30 \mu E \mathrm{~m}^{-2} \mathrm{~s}^{-1}$, and light saturation occurred above about $150 \mu E \mathrm{~m}^{-2} \mathrm{~s}^{-1}$. It is obvious that no horizontal saturation plateau could be obtained in the range $100-200 \mu E \mathrm{~m}^{-2} \mathrm{~s}^{-1}$. This must be due to the fact that in unilaterally illuminated blades of Laminaria $\mathrm{spp}$. the photosynthetic layer on the opposite ('dark') side starts to contribute to the overall photosynthetic rate at concomitantly higher irradiances. Using a recording spectrophotometer (Shimadzu MPS-50L) it was found that a longitudinally halved blade (original thickness $1 \mathrm{~mm}$ ) transmits 1 and $2 \%$ at the absorption maxima (445 and $675 \mathrm{~nm}$, respectively), or $25 \%$ at the absorption minimum (605 nm). Assuming a transmission of $5 \%$ over the whole visible spectrum, one can calculate that an intact blade, which is unilaterally

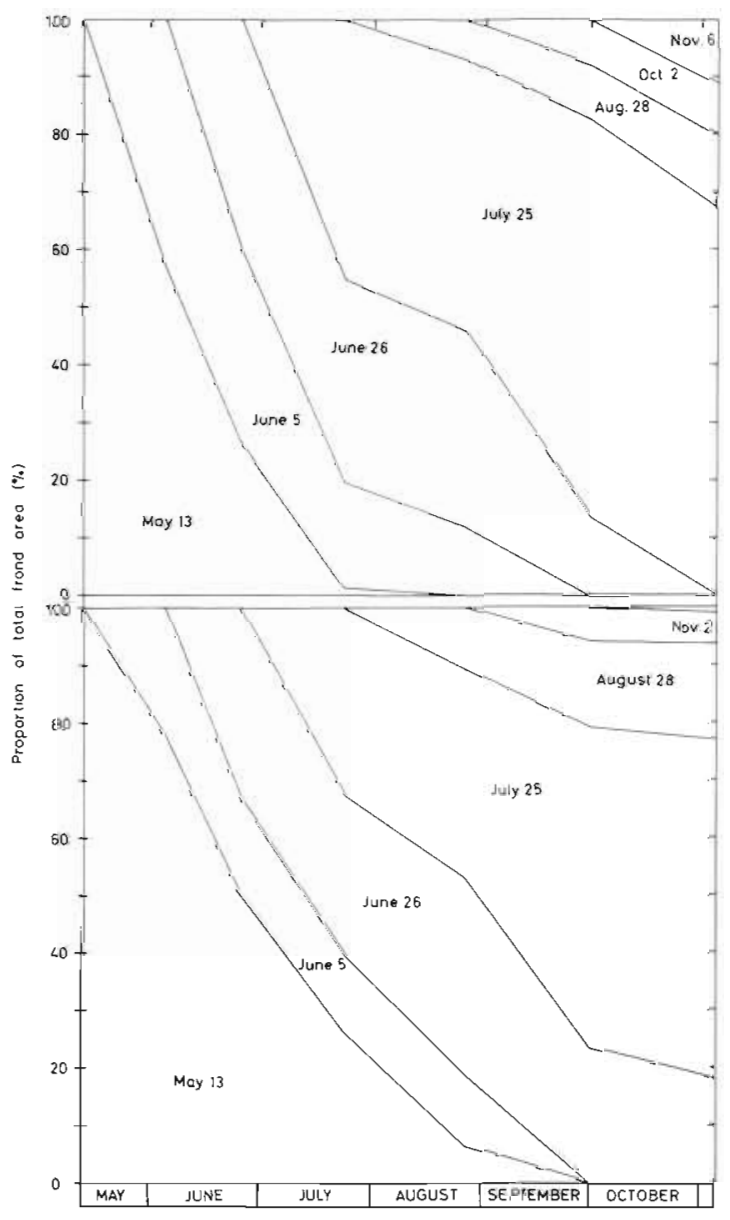

Fig. 10. Laminaria saccharina at $2 \mathrm{~m}$ (upper) and $4.5 \mathrm{~m}$ water depth (lower). Proportion of frond area, newly formed between successive investigation dates, of actual frond area at dates given irradiated with $200 \mu E \mathrm{~m}^{-2} \mathrm{~s}^{-1}$, receives $10 \mu E \mathrm{~m}^{-2} \mathrm{~s}^{-1}$ at the lower side, which is already above the compensation point (Figs 12 and 13). A correction for this effect has been made, and the resulting curves (dotted curves in Figs 12 and 13), which represent the net photosynthesis of the 'upper half' of the blade, indicate a much better saturation plateau. From the intersection of the corrected saturation plateau and the linear part of the $P$ vs $I$ curve an $I_{k}$-value (Talling, 1957) of about $50 \mu \mathrm{E} \mathrm{m}^{-2} \cdot \mathrm{s}^{-1}$ results.

For comparison, the $P$ vs $I$ curves of an eulittoral brown alga and of two sublittoral red algae were also investigated. In Fucus serratus net photosynthesis increased linearly with photon flux density up to $70 \mu \mathrm{E} \mathrm{m}^{-2} \mathrm{~s}^{-1}$ (Fig. 13), and saturation occurred at about $500 \mu E \mathrm{~m}^{-2} \mathrm{~s}^{-1}$. The red algae Delesseria sanguinea and Phycodrys sinuosa were light saturated at $60 \mu \mathrm{E} \mathrm{m}^{-2} \mathrm{~s}^{-1}$. Since the blades of the latter two species are for the most part one layered, a clear horizontal saturation plateau can be seen in these cases (Figs 12 and 13).

The rates of dark respiration, as calculated on an

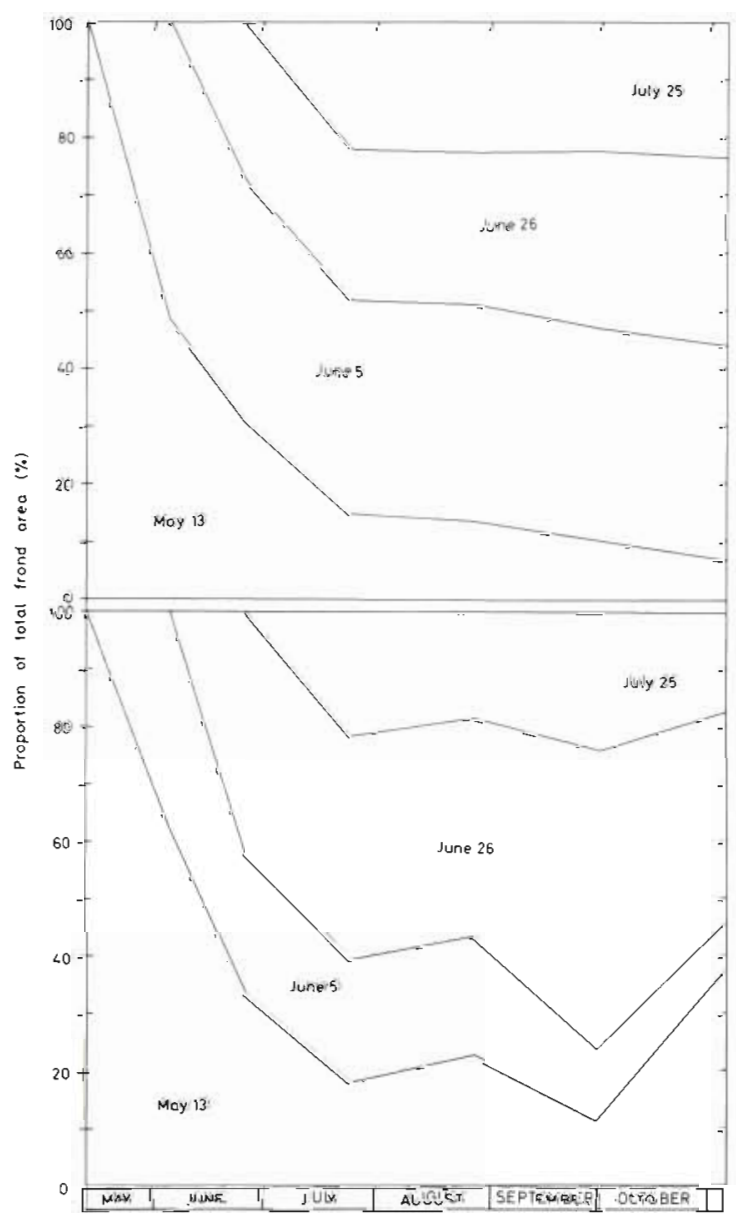

Fig. 11. Laminaria hyperborea at $2 \mathrm{~m}$ (upper) and $4.5 \mathrm{~m}$ water depth (lower). Proportion of frond area, newly formed between successice investigation dates, of actual frond area at dates given 
Table 2. Contents of ash, laminaran, mannitol, and conversion factors for fresh weight (FG) and dry weight (DW) (all mean values) in three Laminaria spp. at different water depths in September. D: L. digitata; S: L. saccharina; H: L. hyperbored; C: cultivated plants; W: wild plants. Number in code: water depth (m below M.L.W.S.); S.D.: standard deviation; N: number of analysed plants; TDW: total dry weight (frond plus stipe plus haptera)

\begin{tabular}{|c|c|c|c|c|c|c|c|c|c|c|}
\hline Parameter & DC2 & DC4 & DW2 & $\mathrm{SC} 2$ & $\mathrm{SC} 4$ & SW2 & $\mathrm{HC} 2$ & $\mathrm{HC} 4$ & $\mathrm{HW}_{2}$ & HW4 \\
\hline$N$ & 20 & 9 & 17 & 20 & 20 & 20 & 11 & 11 & 18 & 20 \\
\hline $\begin{array}{l}\text { Ash }(\% \text { of DW) } \\
\text { S.D. }\end{array}$ & $\begin{array}{r}31.2 \\
3.4\end{array}$ & $\begin{array}{r}35.0 \\
1.1\end{array}$ & $\begin{array}{r}25.4 \\
3.3\end{array}$ & $\begin{array}{r}15.5 \\
2.5\end{array}$ & $\begin{array}{r}25.8 \\
4.3\end{array}$ & $\begin{array}{r}16.9 \\
2.7\end{array}$ & $\begin{array}{r}22.2 \\
4.6\end{array}$ & $\begin{array}{r}29.2 \\
4.3\end{array}$ & $\begin{array}{r}13.1 \\
2.9\end{array}$ & $\begin{array}{r}14.6 \\
2.6\end{array}$ \\
\hline $\begin{array}{l}\text { Laminaran }(\% \text { of DW) } \\
\text { S.D. }\end{array}$ & $\begin{array}{l}2.4 \\
1.8\end{array}$ & $\begin{array}{l}1.4 \\
0.4\end{array}$ & $\begin{array}{l}8.1 \\
2.3\end{array}$ & $\begin{array}{r}21.2 \\
4.2\end{array}$ & $\begin{array}{l}5.1 \\
2.2\end{array}$ & $\begin{array}{r}21.1 \\
2.2\end{array}$ & $\begin{array}{r}10.8 \\
2.7\end{array}$ & $\begin{array}{l}3.8 \\
1.4\end{array}$ & $\begin{array}{r}26.0 \\
6.0\end{array}$ & $\begin{array}{r}19.4 \\
6.8\end{array}$ \\
\hline $\begin{array}{l}\text { Mannitol }(\% \text { of DW) } \\
\text { S.D. }\end{array}$ & $\begin{array}{r}16.3 \\
2.6\end{array}$ & $\begin{array}{l}7.7 \\
1.9\end{array}$ & $\begin{array}{r}18.3 \\
2.0\end{array}$ & $\begin{array}{r}20.3 \\
2.1\end{array}$ & $\begin{array}{r}23.4 \\
3.6\end{array}$ & $\begin{array}{r}18.5 \\
1.3\end{array}$ & $\begin{array}{r}19.9 \\
3.9\end{array}$ & $\begin{array}{r}15.6 \\
4.2\end{array}$ & $\begin{array}{r}15.7 \\
2.9\end{array}$ & $\begin{array}{r}21.9 \\
2.7\end{array}$ \\
\hline $\begin{array}{l}\text { Frond: DW }\left(\mathrm{g} \mathrm{g}^{-1} \mathrm{FW}\right) \\
\text { S.D. }\end{array}$ & $\begin{array}{r}16.2 \\
1.1\end{array}$ & $\begin{array}{r}15.0 \\
0.8\end{array}$ & $\begin{array}{r}17.1 \\
1.9\end{array}$ & $\begin{array}{r}23.0 \\
2.5\end{array}$ & $\begin{array}{r}16.2 \\
2.2\end{array}$ & $\begin{array}{r}20.6 \\
2.5\end{array}$ & $\begin{array}{r}19.8 \\
2.4\end{array}$ & $\begin{array}{r}16.3 \\
1.7\end{array}$ & $\begin{array}{r}27.2 \\
3.1\end{array}$ & $\begin{array}{r}24.2 \\
3.0\end{array}$ \\
\hline $\begin{array}{l}\text { Frond: } D W\left(g \mathrm{dm}^{-2}\right) \\
\text { S.D. }\end{array}$ & $\begin{array}{l}1.10 \\
0.15\end{array}$ & $\begin{array}{l}1.05 \\
0.08\end{array}$ & $\begin{array}{l}1.74 \\
0.28\end{array}$ & $\begin{array}{l}1.96 \\
0.31\end{array}$ & $\begin{array}{l}1.15 \\
0.34\end{array}$ & $\begin{array}{l}2.42 \\
0.24\end{array}$ & $\begin{array}{l}1.30 \\
0.28\end{array}$ & $\begin{array}{l}1.20 \\
0.19\end{array}$ & $\begin{array}{l}3.29 \\
0.64\end{array}$ & $\begin{array}{l}2.35 \\
0.61\end{array}$ \\
\hline $\begin{array}{l}\text { TDW }(g) \\
\text { S.D. }\end{array}$ & $\begin{array}{l}9.7 \\
5.3\end{array}$ & $\begin{array}{l}2.0 \\
1.2\end{array}$ & $\begin{array}{l}40.9 \\
17.0\end{array}$ & $\begin{array}{r}18.1 \\
8.8\end{array}$ & $\begin{array}{l}7.8 \\
6.5\end{array}$ & $\begin{array}{l}33.0 \\
14.5\end{array}$ & $\begin{array}{l}5.8 \\
2.4\end{array}$ & $\begin{array}{l}5.0 \\
2.1\end{array}$ & $\begin{array}{l}82.6 \\
31.3\end{array}$ & $\begin{array}{r}19.6 \\
7.4\end{array}$ \\
\hline $\begin{array}{l}\text { Frond }(\% \text { of TDW) } \\
\text { S.D. }\end{array}$ & $\begin{array}{r}92.2 \\
3.1\end{array}$ & $\begin{array}{r}85.3 \\
5.6\end{array}$ & & $\begin{array}{r}95.8 \\
0.9\end{array}$ & $\begin{array}{r}92.9 \\
2.2\end{array}$ & & $\begin{array}{r}80.6 \\
6.4\end{array}$ & $\begin{array}{r}74.4 \\
5.5\end{array}$ & & \\
\hline $\begin{array}{l}\text { Stipe }(\% \text { of TDW }) \\
\text { S.D. }\end{array}$ & $\begin{array}{l}4.9 \\
2.7\end{array}$ & $\begin{array}{l}5.9 \\
2.7\end{array}$ & & $\begin{array}{l}2.3 \\
0.8\end{array}$ & $\begin{array}{l}3.2 \\
1.2\end{array}$ & & $\begin{array}{l}8.3 \\
2.4\end{array}$ & $\begin{array}{l}8.1 \\
2.0\end{array}$ & & \\
\hline $\begin{array}{l}\text { Laminaran plus } \\
\text { mannitol }\left(\mathrm{q} \mathrm{dm}^{-2}\right)\end{array}$ & 0.17 & 0.09 & 0.15 & 0.21 & 0.25 & 0.16 & 0.24 & 0.16 & 0.13 & 0.18 \\
\hline
\end{tabular}

area base, did not differ significantly according to species (Table 3). The lowest values were encountered in the plants cultivated at $7 \mathrm{~m}$ depth, which also had the thinnest blades. However, the latter aspect was not followed quantitatively.

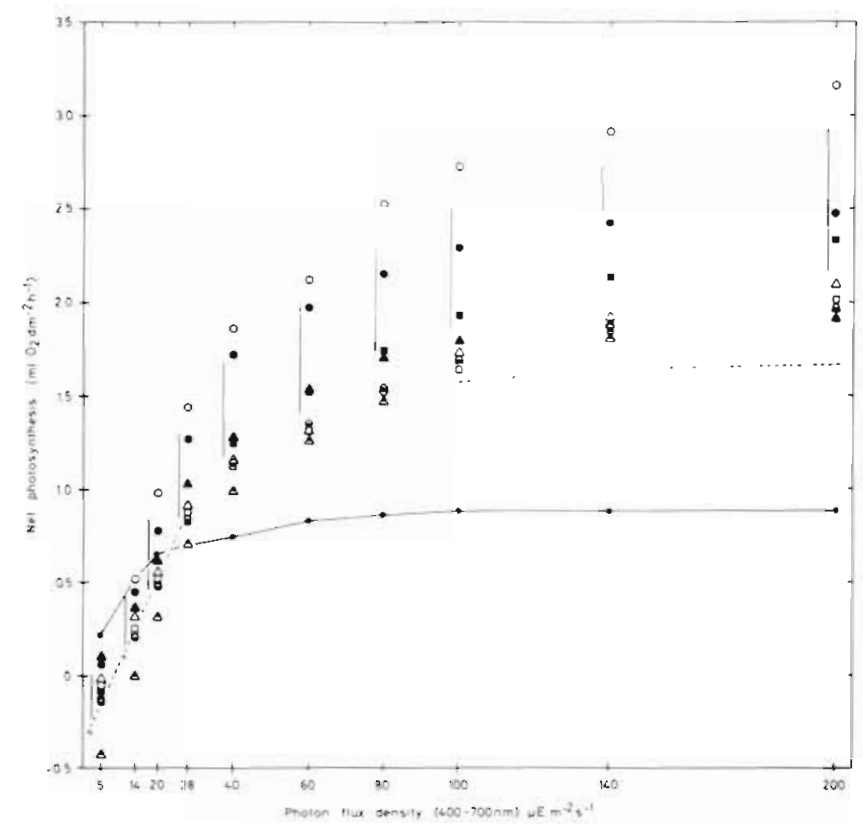

\section{DISCUSSION}

According to the results presented, no species-specific, genetically fixed traits in photosynthetic behaviour (in the sense of sun or shade adaptation) can account for the characteristic depth distribution of the three Laminaria spp. studied. Irrespective of species or depth, saturation of photosynthesis occurred at about 150

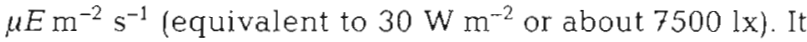
should be noted that these values were measured in late spring and summer. Saturation is likely to occur at somewhat deeper levels in winter (Lüning, 1971). Similar saturation levels have been found in other laminarian species: $10800 \mathrm{~lx}$ in Macrocystis pyrifera (Clendenning, 1971), $10000 \mathrm{~lx}$ in L. japonica (Niihara, 1975), $40 \mathrm{~W} \mathrm{~m}^{-2}$ in Undaria pinnatifida from low water

Fig. 12. Laminarna digitata (circles), L. saccharina (squares), L. hyperborea (triangles) and Delesseria sanguinea (small circles, solid line). Net photosynthesis at different light intensities, as measured from May to June $\left(12^{\circ} \mathrm{C}\right)$. All Laminaria spp. were cultivated at $2 \mathrm{~m}$ (open symbols), $4.5 \mathrm{~m}$ (half filled symbols) or $7 \mathrm{~m}$ (filled symbols) water depth. Regression equation for linear part of $P$ vs $I$ curve (dashed, in range $\left.0-28 \mu \mathrm{E} \mathrm{m}^{-2} \mathrm{~s}^{-1}\right): y=0.45 x-0.36$. Dashed line in range $100-200 \mu \mathrm{E} \mathrm{m}^{-2} \mathrm{~s}^{-1}$ represents $P$ vs $I$ curve, when corrected for transmission of $5 \%$ of incident light $(400-700 \mathrm{~nm})$ by the upper half of the frond (see text for further explanation). Vertical bars: least significant ranges at $p=0.05$ 


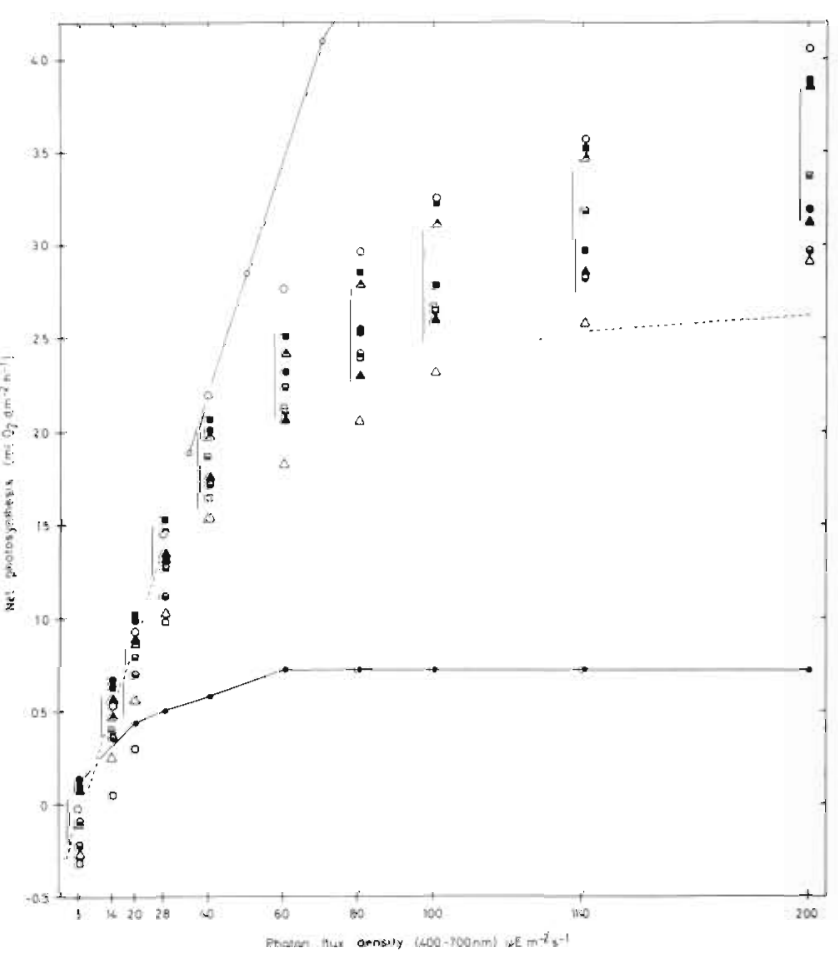

Fig. 13. Laminaria digitata (circles), L. saccharina (squares), L. hyperborea (triangles), Phycodrys sinuosa (small, filled circles; solid line) and Fucus serratus (small, open circles; solid line). Net photosynthesis at different light intensities, as measured in August $\left(17^{\circ} \mathrm{C}\right)$. Regression equation for linear part of $P$ vs $I$ curve (dashed, in range $0-28 \mu \mathrm{E} \mathrm{m}^{-2} \mathrm{~s}^{-1}$ ) : $y=$

$0.59 x-0.38$. For further details see legend to Figure 12

mark and $30 \mathrm{~W} \mathrm{~m}^{-2}$ in Undaria peterseniana from $15 \mathrm{~m}$ water depth (Kageyama \& Yokohama, 1974). Regarding light saturation of photosynthesis, the Laminariales investigated so far can be compared with shade-adapted phytoplankton (sampled at the depth at which $1 \%$ of surface green light can be measured), which is light saturated at about $200 \mu E \mathrm{~m}^{-2} \mathrm{~s}^{-1}$ (equivalent to $44 \mathrm{~W} \mathrm{~m}^{-2}$ ) according to Steemann Nielsen (1975). Together with deep-water red algae, which are light saturated at up to $50 \%$ lower levels, i.e. $10-20 \mathrm{~W} \mathrm{~m}^{-2}$ (Mathieson and Norall, 1975; this study) and might be termed 'extreme shade plants'. The laminarian species
Table 3. Dark respiration $\left(\mathrm{ml} \mathrm{O}_{2} \mathrm{dm}^{-2} \mathrm{~h}^{-1}\right)$ of fronds of three Laminaria spp. cultivated at three water depths (below M.L.W.S.), and measured at two different times during the year. S.D.: standard deviation $(\mathrm{N}=6)$

\begin{tabular}{|c|c|c|c|c|c|}
\hline \multirow[t]{2}{*}{ Species } & \multirow{2}{*}{$\begin{array}{l}\text { Depth } \\
(\mathrm{m})\end{array}$} & \multicolumn{2}{|c|}{$\begin{array}{c}\text { May/June } \\
\left(12^{\circ} \mathrm{C}\right)\end{array}$} & \multicolumn{2}{|c|}{$\begin{array}{l}\text { August } \\
\left(17^{\circ} \mathrm{C}\right)\end{array}$} \\
\hline & & Mean & S.D. & Mean & S.D. \\
\hline \multirow{3}{*}{ L. digitata } & 2 & 0.51 & 0.31 & 0.34 & 0.04 \\
\hline & 4.5 & 0.53 & 0.22 & 0.39 & 0.09 \\
\hline & 7 & 0.19 & 0.06 & 0.22 & 0.08 \\
\hline \multirow[t]{3}{*}{ L. saccharina } & 2 & 0.54 & 0.22 & 0.70 & 0.19 \\
\hline & 4.5 & 0.52 & 0.20 & 0.59 & 0.20 \\
\hline & 7 & 0.50 & 0.28 & 0.25 & 0.06 \\
\hline \multirow[t]{3}{*}{ L. hyperborea } & 2 & 0.42 & 0.16 & 0.69 & 0.23 \\
\hline & 4.5 & 0.79 & 0.22 & 0.42 & 0.13 \\
\hline & 7 & 0.21 & 0.07 & 0.25 & 0.07 \\
\hline
\end{tabular}

can be classified as 'shade plants'. True 'sun plants', such as Fucus spp., are photosynthetically light saturated at about $100 \mathrm{~W} \mathrm{~m}^{-2}$ (Kanwisher, 1966; this study).

The range of maximum net photosynthesis, as determined in this study for the three Laminaria spp. (2-4 ml $\mathrm{O}_{2} \mathrm{dm}^{-2} \mathrm{~h}^{-1}$ ) compares well with the rates reported for other laminarian species (Kain, 1979). In L. saccharina and $L$. digitata the growth rates found in this study can be compared with measurements of length increase of the blade performed by other authors. As can be seen from Table 4, during the first year the maximum increase in blade length is $7-11 \mathrm{~cm}$ week $^{-1}$ in L. saccharina or 3-4 cm week ${ }^{-1}$ in L. digitata (see also Kain, 1979).

It is well known that in the European Laminaria spp. maximum blade growth occurs in late spring, and that adult sporophytes (older than 1 year) of L. hyperborea (Lüning, 1969) stop blade growth in June (except for 'collar' formation; Kain, 1975a), whereas adult sporophytes of L. digitata (Cosson, 1967; Pérez, 1969) and of L. saccharina (Parke, 1948) continue to grow during the second half of the year, although at a reduced rate. As the present study has shown, the differentiation between a 'rapid-growing period' (January to June) and a

Table 4. Increase in frond length in two Laminaria spp. at the locations indicated (seasonal peak values)

\begin{tabular}{|llcccc|}
\hline Species & Location & $\begin{array}{c}\text { Age } \\
\text { (years) }\end{array}$ & Month & $\begin{array}{c}\text { Growth rate } \\
\text { (crn week }{ }^{-1} \text { ) }\end{array}$ & Author \\
\hline L. digitata & Helgoland & 1 & May & 4.1 & This study \\
& Tromsö & 1 & April & 2.9 & Sundene (1964) \\
& Calvados & 2 & May & 8.0 & Pérez (1969) \\
& Helgoland & 1 & June & 10.6 & This study \\
& Wales & 1 & May & 7.0 & Parke (1948) \\
& Wales & 2 & April & 12.1 & Parke (1948) \\
& NE-England & $?$ & May & 8.0 & Burrows and Pybus (1971) \\
\hline
\end{tabular}


'slow-growing period' (July to December) - first made by Parke (1948) and afterwards adopted by Kain (1963) - must be modified for first-year plants of all three Laminaria spp. In the experimental plants of $L$. hyperborea, blade growth stopped completely by the end of July. The same phenomenon had been observed earlier in L. saccharina from the Isle of Man (Parke, 1948) and L. digitata from the coast of Brittany (Pérez, 1969). Also in these cases blade growth was reduced later in the year in first-year plants than in older plants.

It may be speculated that the long-lasting growth period during the first year is related to onset of formation of sporogenous tissue in such a way that the latter process reduces or stops vegetative growth of the blade. Laminaria hyperborea becomes sporogenous at a minimum age of 15 months (Kain, 1975a), L. digitata at 18-20 months (Gayral and Cosson, 1973). Both species were non-sporogenous at the end of the present experiment (in November), i.e. at an age of 14 months (9 months in the sea). L. saccharina from the Isle of Man formed sorus on 6-month-old blade portions (Parke, 1948), the experimental plants of L. saccharina in the present experiment on 4-month-old blade portions. The first-formed sorus, however, occupies only a relatively small area on the blade and is of a more patchy appearance, whereas in older $L$. saccharina plants the whole blade is covered with sorus, except for the wings. The amount of photosynthate required for sorus formation is, hence, probably small during the first year and, consequently, more photosynthate is available for vegetative growth than in later years. Probably, the allocation of photosynthate into either the formation of vegetative or reproductive tissue is not the cause, but only a consequence of the observed species-specific and age-specific seasonal growth patterns; this aspect deserves further investigation

In summer, light intensity is sufficiently high to support photosynthesis of all three Laminaria spp. even at the lower limit of the L. hyperborea forest, which ends at $4 \mathrm{~m}$ water depth (below M. L.W. S.) near Helgoland. From June until August the mean photon flux density $(400-700 \mathrm{~nm})$ was in the range 42-56 $\mu E \mathrm{~m}^{-2} \mathrm{~s}^{-1}$ at this depth (Lüning and Dring, 1979). With this light supply the blades of the Laminaria spp. attain about $70 \%$ of their maximum photosynthetic rate (Figs 12 and 13). The remarkably high growth rates of $L$. digitata and $L$. saccharina at $4.5 \mathrm{~m}$ (Fig. 6), well below the lower limit of their perennial vegetation, are hence not surprising

From October until March only $10 \%$ of total light available per year is received in the sublittoral region near Helgoland, and monthly means of photon flux density $(400-700 \mathrm{~nm})$ at $4 \mathrm{~m}$ water depth are as low as $1-14 \mu E \mathrm{~m}^{-2} \mathrm{~s}^{-1}$ during this period (Lüning and Dring, 1979). Obviously, species inhabiting the deeper sublittoral must be capable of allocating a higher percentage of the carbon fixed in summer into pools of reserve material than species from the upper sublittoral. The dry weight content increases in all three Laminaria spp. in summer and early autumn due to the build-up of mannitol and laminaran, as shown by Black (1950a) for Scottish and by Haug and Jensen (1954) and Jensen and Haug (1956) for Norwegian populations. However, from the measurements of these authors it was also clear that the maximum laminaran content, occurring in September/October, is $50 \%$ lower in L. digitata than in the other two species (Table 5). Similar results were obtained in the present investigation on plants harvested in the field (Table 2). In the plants cultivated this discrepancy was even more pronounced, since in L. digitata only $2 \%$ of the dry weight was laminaran, but in the other two species 11-21\% (Table 2).

In the experimental plants the lowest content of combined mannitol and laminaran was found in Laminaria digitata cultivated at $4.5 \mathrm{~m}$ water depth (90 $\mathrm{mg}$ mannitol and laminaran per $\mathrm{dm}^{2}$, or $14 \%$ of organic weight). However, a few plants of this experimental group also survived the winter, so that the critical content of reserve materials for survival of a laminarian sporophyte near Helgoland must be somewhat lower It seems clear, however, that L. digitata cannot survive the period of limited light supply near

Table 5. Laminaria digitata (D), L. saccharina (S) and L. hyperborea (H). Contents of laminaran and mannitol in Norwegian populations, harvested in September. Values in brackets indicate seasonal maximum, where differing from September values by more than $1 \%$

\begin{tabular}{|c|c|c|c|c|c|c|}
\hline \multirow[t]{2}{*}{ Location } & \multicolumn{3}{|c|}{ Laminaran ( $\%$ of dry weight) } & \multicolumn{3}{|c|}{ Mannitol (\% of dry weight) } \\
\hline & $\mathrm{D}$ & $S$ & $\mathrm{H}$ & $\mathrm{D}$ & $S$ & $\mathrm{H}$ \\
\hline Reine, $1950^{\circ}$ & 10 & 31 & 24 & 17 & 15 & 17 \\
\hline Reine, $1951^{\circ}$ & 16 & 23 & 18 & 15 & 18 & 19 \\
\hline Reine, $1952^{\cdots}$ & $12(15 ;$ Oct. $)$ & - & $23(32 ;$ Nov. $)$ & 15 & - & 17 \\
\hline Espevaer, $1952 *$ & $10(13 ;$ Oct. $)$ & - & 17 (29; Nov.) & 16 & - & 20 \\
\hline \multicolumn{7}{|c|}{$\begin{array}{l}\text { - According to Haug and Jensen (1954). } \\
\text { - According to Jensen and Haug (1956). }\end{array}$} \\
\hline
\end{tabular}


the lower limit of $L$. hyperborea (8 $\mathrm{m}$ depth near Helgoland) due to its restricted capability of building up reserve materials. This is not valid for $L$. saccharina which has a similar potential in this respect to $L$. hyperborea (Tables 2 and 5).

Laminaran and mannitol are interconvertible (Percival and McDowell, 1967), and the increase in laminaran content follows the increase in mannitol with a lag phase of about 2 months (Haug and Jensen, 1954). Several findings indicate that laminaran is formed from mannitol in the same part of the thallus where mannitol was built up due to current photosynthesis. For instance, no translocation occurs in adult sporophytes of Laminaria hyperborea in summer (Lüning et al., 1973). In the blade of L. saccharina, Black (1954) found $0 \%$ laminaran at the base, $10 \%$ at $60 \mathrm{~cm}$ distance, and $30 \%$ at $180 \mathrm{~cm}$ distance. A similar gradient was detected in the blade of a Pacific Laminaria sp. (Powell and Meeuse, 1964). From these findings it can be inferred that the laminaran content present in autumn must be directly related to the longevity of the tissue which fixed carbon at maximum rate in summer. The finding that $80-90 \%$ of the tissue present in June/July still existed in September in $L$. hyperborea and $L$. saccharina, whereas this percentage amounted only to $65 \%$ in the case of L. digitata, again stresses that the main reason why this species does not exist in the deeper kelp region (the 'park' of L. hyperborea on European coasts) is to be sought in its genetically fixed seasonal growth and carbon allocation pattern.

From the middle part of the kelp region, the 'forest' of Laminaria hyperborea, L. digitata and L. saccharina, both adapted for colonization of the upper kelp region by possession of a flexible stipe, are excluded due to competition with L. hyperborea. This has clearly been demonstrated by Kain (1975b, 1976), who cleared rocky areas within the 'forest' of L. hyperborea. One year later, sporophytes of all three Laminaria spp. were present on the experimental areas, but four years later. the rigid stipes of $L$. hyperborea had grown to a sufficient length to allow the formation of a blade canopy of this species, which eliminated all competitors by cutting short their light supply. This is another example for the general rule that the depth survival range of an algal species, limited primarily by coincidence of the physiological and morphological adaptations with the abiotic environment, is furthermore limited and reduced by biological competition (Chapman, 1973b).

Black (1950b), as well as Chapman and Craigie (1978), found that the laminaran content of Laminaria spp. decreased with increasing water depth; a similar trend was observed in the present investigation (Table 2). Hence the build-up of reserve materials does not seem to be regulated in such a way that the sporophytes of a given Laminaria species allocate more photosynthate into reserve materials the deeper they grow. On the contrary, the content in reserve materials at a given time seems to depend directly on photosynthetic production and hence decreases with water depth

The seasonal variation of environmental factors in the sea near Helgoland can be inferred from Figure 14, which also shows the seasonal course of vegetative growth of the experimental plants for comparison. As reported by Chapman and Craigie (1977), the growth of Laminaria longicruris growing at the coast of Nova Scotia is severely $\mathrm{NO}_{3}{ }^{-}$-limited in summer and can be substantially increased by artificial fertilization of the kelp beds. Near Helgoland nutrient concentrations in summer (Fig. 14) are higher than at Nova Scotia, although still below the saturation level for growth of L. saccharina which is ca. $10 \mu \mathrm{M} \mathrm{NO}_{3}^{-}$(Chapman et al.,

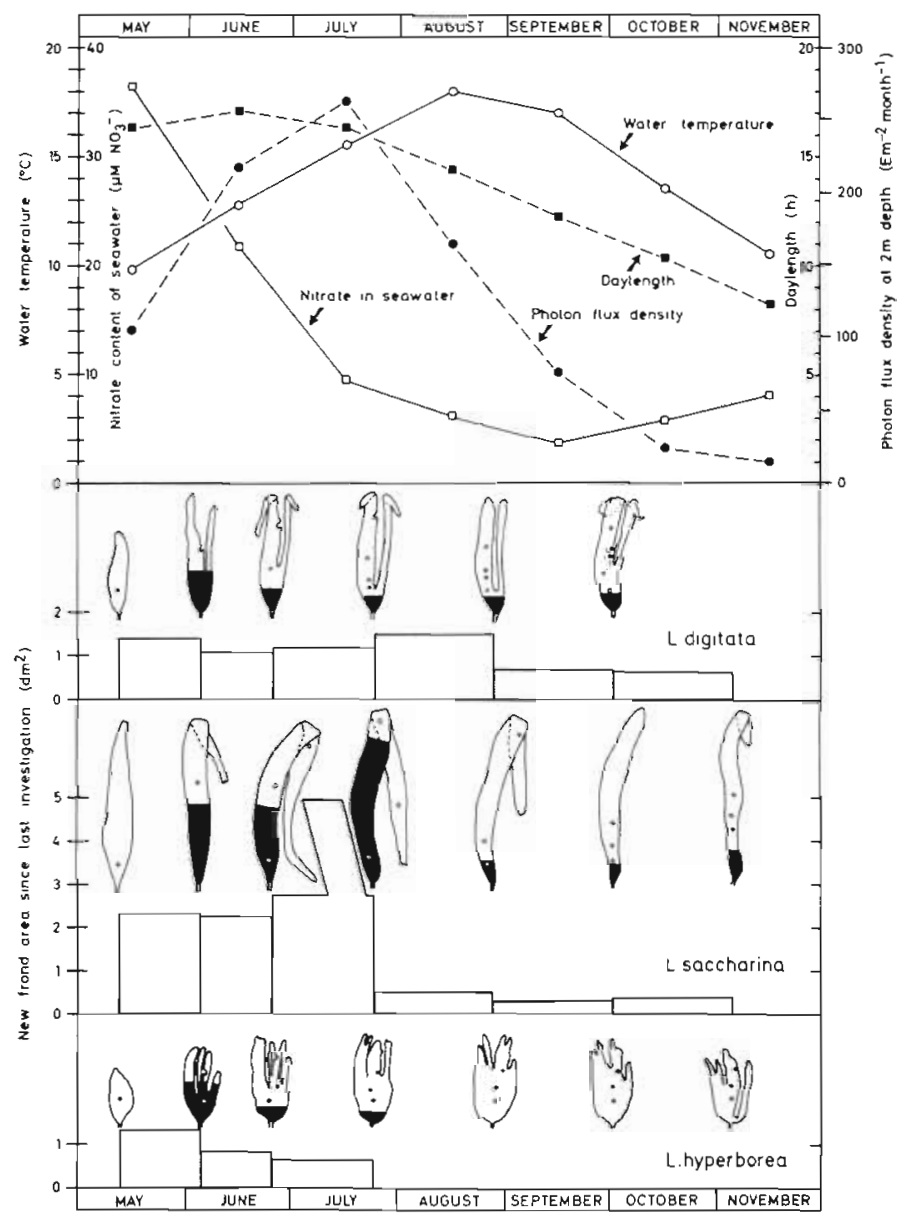

Fig. 14. Helgoland, 1975. Seasonal course of temperature, nitrate concentration of seawater (Harms and Hagmeier, 1976), photon flux density at $2 \mathrm{~m}$ water depth (Lüning and Dring, 1979), daylength (according to Smithsonian Meteorological Tables, 1951), and of frond area increase in experimental sporophytes of three Laminaria spp. (hatched areas), cultivated at $2 \mathrm{~m}$ water depth (filled area in outline drawings: new-formed tissue) 
1978). The finding in the present work that during the first year of life L. hyperborea stopped its growth completely and $L$. saccharina reduced its growth rate considerably by the end of July (ambient $\mathrm{NO}_{3}{ }^{-}$concentration $8 \mu \mathrm{M}$ ), but $L$. digitata by $50 \%$ only in September (ambient $\mathrm{NO}_{3}^{-}$concentration $3-4 \mu \mathrm{M}$ ) suggests that nutrient concentration is only a secondary, but not the triggering, factor for termination or reduction of vegetative growth. The possibility that the seasonal course of reserve carbon accumulation per se might trigger the onset of late winter growth in $L$. longicruris had been ruled out by Chapman and Craigie (1978).

For microscopic laminarian gametophytes a broad temperature optimum has been recorded to occur above $10^{\circ} \mathrm{C}$, with inhibition acting near $20^{\circ} \mathrm{C}$ (Kain, 1965, 1969; Pérez, 1971; Cosson, 1973). Since water temperature rises up to $18{ }^{\circ} \mathrm{C}$ near Helgoland, it might be possible that some of the reduction in growth rate is due to elevated temperatures. However, that Laminaria hyperborea did not resume growth in October, when water temperature fell below $15^{\circ} \mathrm{C}$ (Fig. 14), makes it also unlikely that temperature, provided it is not near the lethal limit, is a triggering factor for vegetative growth. The same applies to photon flux density which in August, at $2 \mathrm{~m}$ water depth, was still as high as $164 \mathrm{E} \mathrm{m}^{-2}$ month $^{-1}$ (Fig. 14) or $102 \mu \mathrm{E} \mathrm{m}^{-2} \mathrm{~s}^{-1}$ (conversion by use of daylength $=14.4 \mathrm{~h}$ ). This means that the experimental plants of $L$. hyperborea and $L$. saccharina, which stopped or reduced their growth by the end of July, were still photosynthetically lightsaturated in August (Figs 12 and 13).

One is then left with the theoretical possibility that either a circannual rhythm is involved in the regulation of seasonal growth, as suspected in the case of. Alaria esculenta (Buggeln, 1978), or that photoperiodism is involved. The first possibility would be difficult to prove (Sweeney, 1969; Pengelly, 1974), and no experimental evidence has been produced so far to support the second hypothesis. The seasonal development of the gametophytes of the Laminariales investigated to date is definitely not under photoperiodic control (Lüning, 1980b). This does not exclude the possibility that photoperiod controls the development of the laminarian sporophyte, i.e. its vegetative growth behaviour and/or the onset of sporangia formation. This problem, which is also important for aquaculture prospectives with laminarian species, must now be tackled experimentally.

\section{LITERATLRE CITED}

Black, W A. P. (1950a). The seasonal variation in weight and chemical composition of the common British Laminariaceae. J. mar biol. Ass. U.K, 29, 45-72.
Black, W. A. P. (1950b). The effect of the depth of immersion on the chemical constitution of some of the sub-littoral seaweeds common to Scotland. $J$. Soc chem. Ind., Lond., $69,161-165$.

Black, W. A. P. (1954). Concentration gradients and their significance in Laminaria saccharina (L.) Lamour $J$. mar. biol. Ass. U.K., 33, 49-60.

Buggeln, R. G. (1978). Physiological investigations on Alaria esculenta (Laminariales, Phaeophyceae). IV Inorganic and organic nitrogen in the blade. J. Phycol., 14, 156-160

Burrows, E. M and Pybus, C. (1971). Laminaria saccharina and marine pollution in north-east England. Mar. Pollut. Bull, NS, 2, 53-56.

Cameron, M. C., Ross. A. G. and Percival, E. G. V (1948). Methods for the routine estimation of mannitol, alginic acid, and combined fucose in seaweeds. J. Soc chem. Ind., Lond., 67, 161-164.

Castric-Fey, A., Girard-Descatoire, A., Lafargue, F. and L'Hardy-Halos, M. T (1973). Etagement des algues et des invertébrés sessiles dans l'Archipel de Glénan. Helgoländer wiss. Meeresunters., 24, 490-509.

Chapman, A. R. O. (1973a). Methods for macroscopic algae. In J. R. Stein (Ed.)., Handbook of Phycology. University Press, Cambridge, pp. 87-104.

Chapman, A. R. O. (1973b). A critique of prevailing attitudes towards the control of seaweed zonation on the sea shore. Botanica mar., 16, 80-82.

Chapman, A. R. O. and Craigie, J. S. (1977). Seasonal growth in Laminaria longicruris: relations with dissolved inorganic nutrients and internal reserves of nitrogen. Mar. Biol., 40, 197-205.

Chapman, A. R. O. and Craigie, J. S. (1978). Seasonal growth in Laminaria longicruris: relations with reserve carbohydrate storage and production. Mar. Biol., 46, 209-213.

Chapman, A. R. O., Markham, J. W and Lüning, K. (1978). Effects of nitrate concentration on the growth and physiology of Laminaria saccharina (Phaeophyta) in culture. $J$. Phycol., 14, 195-198.

Clendenning, K. A. (1971). Photosynthesis and general development in Macrocystis. Nova Hedwigia (Beih.), 32, $169-190$

Cosson, J. (1967). Etude d'une population de Laminaria digitata Lam. (biométrie, croissance, régéneration). Bull. Soc. linn. Normandie, 8, 246-281

Cosson, J. (1973). Influence des conditions de culture sur le développement de Laminaria digitata (L.) Lam. (Phèophycèes, Laminariales). Bull Sor. phycol. Fr., 18, 104-112.

Evans, G. C. (1972). The Quantitative Analysis of Plant Growth, Blackwell, Oxford.

Gayral, P. and Cosson, J. (1973). Exposé synoptique des données biologiques sur la laminaraire digitée Laminaria digitata. Synop. FAO Pêches, 89.

Green, E. J. and Carritt, D. E. (1967). New tables for oxygen saturation of seawater $J$. mar. Res., 25, 140-147.

Harms, E and Hagmeier, E. (1976). Hydrographie, Chemie und Planktongehalt des Wassers bei Helgoland. In Jahresbericht 1975. Brologische Anstalt Helgoland, Hamburg. pp. $21-27$

Haug, A. and Jensen, A. (1954). Seasunal variations in the chemical composition of Alaria esculenta, Laminaria saccharina, Laminaria hyperborea and Laminaria digitata from Northern Norway. Norsk institutt for tang-og tareforskning, rep., 4, 1-1.4.

Jensen, A. and Haug, A. (1956). Geographical and seasonal variation in the chemical composition of Laminaria hyperbored and Laminaria digitata from the Norwegian coast. Norsk institutt for tang-og tareforskning, rep., 14, 1-8. 
Kageyama, A. and Yokohama, Y (1974). Photosynthetic properties of marine benthic brown algae from different depths in coastal areas. Bull. Jap. Soc. Phycol, 22, 119-123.

Kain, J. M. (1962). Aspects of the biology of Laminaria hyperborea. I. Vertical distribution. J. mar. biol. Ass. U. K. 42 , 377-385.

Kain, J. M. (Mrs. N. S. Jones) (1963). Aspects of the biology of Laminaria hyperborea. II. Age, weight and length. J. mar. biol. Ass. U. K., 43, 129-151

Kain, J. M. (Mrs. N. S. Jones) (1965). Aspects of the biology of Laminaria hyperborea. IV. Growth of early sporophytes. $J$. mar. biol. Ass. U.K., 45, 129-143.

Kain, J. M. (Mrs. N. S. Jones) (1969). The biology of Laminaria hyperborea. $\mathrm{V}$ Comparison with early stages of competitors. J. mar biol. Ass. U.K., 49, 455-473.

Kain, J. M. (Mrs. N. S. Jones) (1975a). The biology of Laminaria hyperborea. VII. Reproduction of the sporophyte. J. mar. biol. Ass. U.K., 55, 567-582.

Kain, J. M. (Mrs. N. S. Jones) (1975b). Algal recolonization of some cleared subtidal areas. J. Ecol. 63, 739-765

Kain, J. M. (Mrs. N. S. Jones) (1976). The biology of Laminaria hyperborea. VIII. Growth on cleared areas. J. mar. biol. Ass. U.K., 56, 267-290.

Kain, J. M. (Mrs. N. S. Jones) (1979). A view of the genus Laminaria. Oceanogr. mar. Biol., in press.

Kanwisher, J. W (1966). Photosynthesis and respiration in some seaweeds. In H. Barnes (Ed.), Some Contemporary Studies in Marine Sciences. Allen \& Unwin, London. pp. $407-420$.

Lüning, K. (1969). Growth of amputated and dark-exposed individuals of the brown alga Laminaria hyperborea. Mar. Biol., 2, 218-223.

Lüning, K. (1971). Seasonal growth of Laminaria hyperborea under recorded underwater light conditions near Helgoland. In D. J. Crisp (Ed.), Proceedings of the 4th European Marine Biology Symposium. University Press, Cambridge. pp. $347-361$

Lüning, K. (1980a). Critical levels of light and temperature regulating the gametogenesis of three Laminaria spp. (Phaeophyceae). J. Phycol, in press.

Luining. K. (1980b). Control of algal life history by daylength and temperature. In Systematics Association Special Volume, in press.

Lüning, K., Chapman, A. R. O. and Mann, K. H. (1978) Crossing experiments in the non-digitate complex of Laminaria from both sides of the Atlantic. Phycologia, 17, 293-298.

Lüning, K. and Dring, M. J. (1975). Reproduction, growth and photosynthesis of gametophytes of Laminaria saccharina grown in blue and red light. Mar. Biol, 29, 195-200.
Lüning, K. and Dring, M. J. (1979). Continuous underwater light measurement near Helgoland (North Sea) and its significance for characteristic light limits in the sublittoral region. Helgoländer wiss. Meeresunters., 32, 403-424.

Lüning, K., Schmitz, K. and Willenbrink, J. (1973). $\mathrm{CO}_{2}$ fixation and translocation in benthic marine algae. III. Rates and ecological significance of translocation in Laminaria hyperborea and L. saccharina. Mar. Biol., 23, 275-281.

Mathieson, A. C. and Norall, T L. (1975). Physiological studies of subtidal red algae. J. exp. mar. Biol. Ecol., 20, $237-247$

Niihara, Y (1975). Physiological studies of Laminaria japonica var ochotensis. The effect of temperature, light intensity and salinity upon photosynthesis and respiration of young sporophytes. Hokkaido-Ritsu Suisan Shikenjo. Yoichi, Jap., 17, 11-17.

Parke, M. (1948). Studies on British Laminariaceae. I. Growth in Laminaria saccharina (L.) Lamour $J$. mar. biol. Ass. U. K., 27, 651-709.

Pengelly, E. T. (1974). Circannual Clocks, Annual Biologica) Rhythms, Academic Press, New York.

Percival, E. and McDowell, R. (1967). Chemistry and Enzymology of Marine Algal Polysaccharides, Academic Press.

Pérez, R. (1969). Étude biomètrique d'une population de Laminaria digitata Lamouroux de l'étage infralittoral profond. Revue Trav. Inst. (scient. tech.) Pêch. marit., 33, $117-135$.

Pérez, R. (1971). Influence de quelques facteurs physiques sur le développement de Laminaria digitata (L.) Lamour. Bull. Soc. phycol. Fr., 16, 89-105.

Powell, J. H. and Meeuse, B. J. D. (1964). Laminarin in some Phaeophyta of the Pacific coast. Econ. Bot., 18, 164-166.

Provasoli, L. (1968). Media and prospects for the cultivation of marine algae. In A. Watanabe and A. Hattori (Eds), Cultures and Collections of Algae. (Proc. Jap. Conf. Hakone, 1966). Jap. Soc. Plant Physiol., Tokyo. pp. 63-75

Smithsonian Meteorological Tables (1951). Duration of daylight. Smithson. misc. Collns, 114, 507-512.

Steemann-Nielsen, E. (1975). Marine photosynthesis, Elsevier, Amsterdam.

Sundene, O. (1964). The ecology of Laminaria digitata in Norway in view of transplant experiments. Nytt. Mag. Bot., 11, 83-107.

Sweeney, B. M. (1969). Rhythmic phenomena in plants, Academic Press, London

Talling, J. F. (1957). The phytoplankton population as a compound photosynthetic system. New Phytol., 56, 133-149. 